\title{
Z Kresów do Poznania. Mikrohistoria Waldemara Żyszkiewicza
}

\section{From Kresy to Poznan. Waldemar Żyszkiewicz's Microstories}

\author{
|Agnieszka Rydz
Uniwersytet im. Adama Mickiewicza w Poznaniu
}

\begin{abstract}
The article focuses on a description of political events in the 20th century Poland which were reflected in the poetry of Waldemar Żyszkiewicz. An important topic is a migration of the Polish over the period 1944-1947. His poetry, though conforms to the discourse of nostalgia, does not evoke the images of the lost Lvov. Poems raise the theme of settling down by deportees from Kresy Wschodnie (Eastern borderlands) in Poznan, an area were German culture was cultivated. The theoretical inspiration for the article was provided above all by two monographs by Beata Halicka "Polski Dziki Zachód" ("The Polish Wild West", 2016) and by Ewa Domańska "Mikrohistorie" (Microstories, 1999).

Key words: Waldemar Żyszkiewicz, Polish poetry, Eastern borderlands, microstories, migration

Streszczenie: Artykuł przynosi omówienie wydarzeń politycznych w Polsce w XX wieku zarejestrowane w poezji Waldemara Żyszkiewicza. Ważnym tematem jest zjawisko migracji Polaków z lat: 1944-1947. Poezja ta, mimo że wpisuje się w dyskurs nostalgii, nie przynosi obrazów utraconego Lwowa. Wiersze poruszają temat osiedlenia się przez wysiedleńców z Kresów Wschodnich w Poznaniu, w obcym dla nich mieście, nacechowanym niemiecką kulturą. Inspiracją teoretyczną dla artykułu były przede wszystkim monografie: Beaty Halickiej Polski Dziki Zachód (2016) oraz Ewy Domańskiej Mikrohistorie (1999).
\end{abstract}

Słowa kluczowe: Waldemar Żyszkiewicz, Kresy, poezja polska, mikrohistoria, migracja

Mimo że fale migracji ludności cywilnej u schyłku II wojny światowej są zjawiskiem ogromnym, to lapidarne podsumowanie zjawiska znajdziemy w urywku wspomnień Huberta Orłowskiego. W pamięci profesora poznańskiej germanistyki wydarzenia sprzed ponad siedemdziesięciu lat zapisały się w sposób dramatyczny: „rok 1945 to czas ucieczek na zachód [podkr. A.R.]" (Orłowski 1997, 12). Trzymając się historycznej faktografii, można dopowiedzieć, że była to desperacka ucieczka Zachodu przed Wschodem, napierającym już nań w zwycięskim marszu na Berlin. Jednocześnie 
w wyniku rozstrzygnięć „Wielkiej Trójki”: Winstona Churchilla (premiera Wielkiej Brytanii), Franklina Delano Roosevelta (prezydenta Stanów Zjednoczonych) oraz Józefa Stalina (przywódcy Związku Radzieckiego) na konferencji w Jałcie, na Krymie (4-11 lutego 1945 roku) przypieczętowano terytorialny podział Europy na sfery wpływów poszczególnych negocjatorów. Dla Polaków decyzje mocarstw oznaczały przede wszystkim przesunięcie granic państwowych na mapie politycznej świata w kierunku zachodnim. Utrata rodzinnego domu i własnego miejsca na ziemi bezpośrednio łączyła się $\mathrm{w}$ biografiach polskich obywateli zamieszkujących Kresy Wschodnie przedwojennej Rzeczypospolitej z przywołanymi faktami historycznymi. Z kolei emocjonalne i na wskroś prywatne świadectwa przeżycia ówczesnych zdarzeń przez ich uczestników, a także praktyki mitologizujące doświadczenie utraty ojczystych stron wpisały się do kanonu literatury kresowej powstałego po 1945 roku i poszerzanego o nowe zjawiska po przełomie 1989 roku.

\section{Migracje}

Na lata 90. XX wieku przypada wzmożone zainteresowanie przedstawicieli różnych dyscyplin naukowych zjawiskiem przymusowych migracji w Europie po II wojnie światowej. Beata Halicka, omawiając temat osadnictwa na Ziemiach Zachodnich, przyłączonych do Polski w 1945 roku, nawiązuje do badań rozwijających się współcześnie w Niemczech, nierzadko we współpracy z Polakami. Między innymi przywołuje pracę Ingrid Oswald z 2007 roku, która zdefiniowała migrację jako złożony „proces przestrzennego przeniesienia swojego stałego pobytu - a więc niektórych bądź wszystkich istotnych dziedzin życia - w inne miejsce, któremu towarzyszy doświadczenie społecznej, politycznej i/lub kulturowej cezury" (Halicka 2015 , 25). Widać więc, że migracja, po pierwsze, oznacza radykalną zmianę miejsca, w związku z czym ma ona zdolność przemodelowania całej ludzkiej egzystencji, zupełnie niezależnie od tego, czy proces deprywacji przebiega w sposób aktywny jako wynik indywidualnego wyboru (ucieczka, migracja zarobkowa), czy pasywny, jak podczas deportacji. Po drugie, jest ona rodzajem doświadczenia granicznego w podwójnym sensie: raz, gdyż dotyczy granic ujętych terytorialnie jako granice państw narodowych, dwa, gdy chodzi o podziały rozumiane inaczej aniżeli układy przestrzenne, czyli obramowanie Ja: osobiste, psychiczne, psychospołeczne. Z kolei trzeci aspekt doświadczenia migracji wprowadza zmianę w obręb sieci relacji społecznych, w jakim funkcjonuje konkretna osoba.

Doświadczenie specyficznej migracji powojennej polskich Kresowian doczekało się opracowań przez historyków i socjologów, ale z kilku powodów, z których najważniejszym była w przeszłości cenzura polityczna w PRL-u nazywano je oraz interpretowano w różny sposób (Bakuła 1997, 235). Poniżej podaję kilka popularnych określeń używanych na oddanie 
powojennego przymusowego przemieszczania polskich obywateli z terenów, które po II wojnie zostały wcielone do ZSRR:

- repatriacja: «powrót obywateli jakiegoś kraju do ojczyzny, np. jeńców wojennych, uchodźców, przesiedleńców; repatriowanie (się)» (PWN, 3),

- migracja: «wędrówka, ruch ludności mający na celu zmianę miejsca pobytu na stałe lub okresowo, zarówno w obrębie kraju, jak i z jednego kraju do drugiego; przenoszenie się, przesiedlanie ludności» (PWN, 1),

- deportacja: «kara polegająca na skierowaniu skazanego do odległej miejscowości na przymusowy pobyt; zesłanie» (PWN, 1),

- $\quad$ przesiedlać się: «zmienić miejsce stałego pobytu, zamieszkania; osiedlić się w innej miejscowości, w innym kraju itp.»(PWN, 2),

- $\quad$ przesiedlić: «przenieść kogoś (coś) na inne miejsce stałego pobytu, zamieszkania; osiedlić w innej miejscowości, w innym kraju itp.» (PWN, 2),

- $\quad$ wysiedlić: «zmusić kogoś do opuszczenia miejsca zamieszkania; usunąć kogoś ze stałej siedziby» (PWN, 3).

Przypomnijmy w tym miejscu, że na mocy traktatów międzypaństwowych ludność polska z obszaru Ukraińskiej Socjalistycznej Republiki Radzieckiej (Lwów) oraz z okolic Wilna i zachodniej Białorusi miała zostać objęta wymianą między Polską a ZSRR. Uprawnieni do wyjazdu byli Polacy i Żydzi, do 17 września 1939 roku posiadający polskie obywatelstwo, którzy musieli złożyć formalny wniosek w sprawie repatriacji, inaczej niejako „automatycznie” narzucano im obywatelstwo radzieckie. Wstępne porozumienia podpisano jeszcze we wrześniu 1944 roku, zanim sprawa granic między Polską, Ukrainą, Litwą i Białorusią została oficjalnie uregulowana. Wtedy też pojawił się termin „repatriacja”, który - co widać w definicji słownikowej - nie odpowiadał ani realiom politycznym, ani społecznym, ani nawet językowym, za to służył potrzebom propagandowym rządu PKWN oraz przez cały PRL. Pojęcie „repatriacja” odnosi się bowiem do obywateli państwa powracających do ojczyzny spoza jej granic. Tu jednak sytuacja była odwrotna: to ludność z kraju rodzimego była przymuszana do wyjazdu i osiedlania się w nowym miejscu albo gdzieś w Polsce, albo w przypadku Ziem Zachodnich (w pasie od Wrocławia po Szczecin) - osiedliny odbywały się nawet w obcym kraju, gdzie ludność kresowa zajmowała obszar opuszczony przez wypędzonych po wojnie Niemców. Triada pokrewnych morfologicznie czasowników: „przesiedlać się” - „przesiedlić” (kogoś) - „wysiedlić” (kogoś) obrazuje dotkliwą różnicę między dobrowolnym przesiedleniem, oznaczającym zmianę zamieszkania, a wysiedleniem, do którego dochodzi na skutek zewnętrznego przymusu. W swej istocie doświadczenie repatriacji okazało się dla objętej nią ludności bliższe karnym deportacjom niż zwykłym przenosinom z miejsca na miejsce w obrębie 
granic państwa i - przede wszystkim - w wyniku indywidualnego wyboru, którego została pozbawiona.

Najwcześniej, bo już 15 października 1944 roku, rozpoczęto przesiedlenia Polaków zamieszkujących republikę ukraińską ZSRR. Nie chciano zwlekać z przeprowadzeniem akcji, bo wydarzenia ludobójstwa na Wołyniu (1943-1945, z kulminacją okrucieństwa w lecie 1943 roku) uniemożliwiały dalszą koegzystencję obu narodów. Zresztą biorąc pod uwagę fakt czystek etnicznych, jakich ofiarami padła ludność polska w trakcie „rzezi wołyńskiej" (Smarzowski 2016, Motyka 2016, Snyder 2009), adekwatne byłoby traktowanie jej jako wojennych uchodźców zamiast eufemistycznego określania „repatriantów”. Było to kolejne tabu czasu wojny, a jeszcze bardziej PRL-u. Natomiast na Litwie i Białorusi akcję prowadzono od 1 grudnia 1944 roku. Trudno było o gorszy termin. Zimne jesienne i zimowe miesiące, na jakie przypadł początek akcji, oznaczały dla przesiedleńców podróż wielotygodniową, wyczerpującą z powodu niskich temperatur, chorób i głodu oraz dodatkowo przerywaną kilkudniowymi postojami z powodu przemieszczania się wojska. Brakowało też kolejowego taboru, a niejednokrotnie nie było nawet żadnego planu, dokąd miałby taki pociąg pojechać. Ponieważ transfer ludności na taką skalę w praktyce stwarzał ogromną trudność: nadal toczyła się wojna, nierozwinięta była jeszcze logistyka, powszechnie panował niedobór wszystkiego (prowiantu dla ludzi i zwierząt, środków transportu, paliw), toteż pierwotnego terminu zakończenia repatriacji, obliczonego na początek roku 1945, oczywiście nie udało się dotrzymać. Natomiast do sprawnego przeprowadzenia akcji wysiedleń Stalin „mobilizował" polski rząd w ten sposób, że zimą 1944/1945 wzmógł represje na Polakach, między innymi wywożąc ich na Syberię pod zarzutem krzewienia polskiego nacjonalizmu (Halicka 2015, 167). Mimo że z pozoru wymiana ludności następowała według zasad prawa międzynarodowego, to na okolicznościach transferu zaważyły głównie dwa fakty: trwająca wojna oraz podporządkowanie komunistycznych władz Polski oraz republik Związku Radzieckiego (Ukraina, Białoruś, Litwa) dyktaturze Stalina. Halicka tę część monografii, w której rekonstruowała historyczno-polityczne kulisy wysiedleń Kresowian, zatytułowała w wymowny sposób: Tak zwana repatriacja Polaków z Kresów - w bydlęcych wagonach na łono ojczyzny? (Halicka 2015, 159-160). Od dramatycznych przesiedleń upłynęło już siedemdziesiąt lat i najwyższa pora, żeby popularyzować nowe spojrzenie na temat, choćby za pomocą książek, jakie powstały w ostatnich latach (Grzebałkowska 2015, Zaremba 2012).

\section{Mikrohistoria}

Termin: „mikrohistoria” w zamyśle jego pomysłodawczyni, Ewy Domańskiej (Domańska 2005), powstał na gruncie przeprowadzonej przez nią krytyki historii w jej postmodernistycznym nurcie, a jeszcze bardziej 
w rezultacie intelektualnych poszukiwań prowadzonych na terenie innych dyscyplin aniżeli macierzysta historia. Badaczka z Poznania wskazała na inspirujące ją prace $\mathrm{z}$ zakresu teorii literatury (Roland Barthes) oraz antropologii (Clifford Geertz) oraz na dekonstrukcyjne rozprawy Jacquesa Derridy i Michela Foucaulta. Jakkolwiek autorka koncepcji nie tworzy ścisłej definicji pojęcia mikrohistorii, to znajdziemy w książce deskrypcję owej - jak ją nazywa - „historii alternatywnej”, czyli synonimu mikrohistorii, różnej zarówno od tradycyjnych ujęć dyscypliny, jak też od jej postmodernistycznych rewizji. Domańska charakteryzuje mikrohistorię w opisie na tyle rozbudowanym, że można wytworzyć sobie wyobrażenie celów oraz zakresu problematyki tej pogranicznej dziedziny nauki:

Opowiada ona o człowieku, który został „wrzucony” w świat, o ludzkim byciu w świecie, o ludzkim doświadczaniu świata i o sposobach tego doświadczania. Jest to zatem historia doświadczeń, historia uczuć, prywatnych mikroświatów [podkr. A.R.]. Człowieka i jego losy poznajemy za pośrednictwem <<cases $>>$ (przypadków), <<miniatur $>$, antropologicznych opowieści, które jak sonda pozwalają wniknąć w codzienną rzeczywistość. Krytyka związana z <<wielkimi narracjami >> (marksizm) historii w skali makro oraz redukcja skali, zaproponowana przez szukających dla niej alternatywy badaczy, spowodowała, że ów rodzaj pisarstwa historycznego określono mianem <<mikrohistorii >> (od włoskiego słowa $<<$ microhistoria $>>$ ) (Domańska 2005, 62-63).

Ponadto na określenie takiej odmiany historiografii (jak powyżej opisana przez Domańską) - zatem: ukierunkowanej na analizę doświadczeń zwykłych ludzi - używana jest też nazwa „nowa historia kulturowa” (Domańska 2005, 58). Znajdziemy w niej nawiązania do antropologicznych inspiracji autorki oraz metodologii bazującej z jednej strony na empirii (prymat doświadczenia nad abstrakcją), a z drugiej - na dziedzictwie autobiograficznym reprezentowanym przez dzienniki oraz przekazy pamiętnikarskie. Dlatego dla części badaczy mikrohistoria to przede wszystkim wyraz antropologicznego podejścia do przeszłości, a nie odrębna gałąź historii. Zostawmy jednak spory historyków, przecież nie one są tu najistotniejsze. $\mathrm{Z}$ mojego punktu widzenia ważne zostaje utrzymane w tej koncepcji pokrewieństwo z metodą antropologiczną, zorientowaną na deskrypcję codziennego życia człowieka i doświadczeń dostępnych każdemu, co Domańska określiła, mówiąc o wprowadzeniu „ludzkiej” perspektywy do badań i percepcji zdarzeń historycznych. We wstępnym rozwinięciu tego pomysłu postawiłabym tezę, że Polacy mieszkający na wschodnich kresach przedwojennej Rzeczypospolitej to grupa reprezentatywna dla nowej historii kulturowej z wielu powodów. Głównie dlatego, że w przypadku Kresowian bezlitosna konfrontacja wielkiej polityki, na jaką zwykły człowiek nie ma wpływu, z autobiograficzną kruchością życia, sprawiła, że powstał rozziew między próbami interpretacji własnego położenia przez Ja doświadczające (podmiot empiryczny) i zarazem Ja doświadczane (podmiot traumy), poddawane próbie przez „twardy” los. Jednocześnie chiazmatyczna zależność 
zachodząca między polityką światowych mocarstw a indywidualną biografią, między egzystencją a traumą, między skalą zdarzenia a możliwością jego przyswojenia przez Ja, w końcu - między życiem a śmiercią, warunkuje zdaniem Domańskiej w ogóle narodziny świadomości historycznej w Europie, ponieważ - jak czytamy dalej w sformułowanym przez nią uzasadnieniu:

Jedynymi momentami, w których rzeczywistość (przeszłość) odkrywa nam swoje prawdziwe oblicze, są chwile traumy będącej zaskoczeniem, raną (gr. <<trauma >>) zadawaną nam przez świat. Trauma i wzniosłość powodują, że nasze przekonania, kategorie i oczekiwania roztrzaskują się na fragmenty [podkr. A.R.]. Doświadczenia nietraumatyczne nie mają takiej mocy, poddane są bowiem przemocy już znanego, oswojonego. Realna historia tworzy się jako rezultat traumatycznych doświadczeń zbiorowych. Historia jest zatem - jak napisał Fredric Jameson - tym, co rani (Domańska 2005, 123).

Dlatego doświadczenie swoistego rozpadu świata, jakie pod przymusem stało się udziałem Polaków wysiedlonych ze wschodnich regionów przedwojennej Polski, daje się porównać z traumatogennymi doznaniami leżącymi u podstaw funkcjonowania historii, „która rani”. Po rozpadzie małej ojczyzny trzeba było podjąć próbę odbudowy zniszczonego życia, a w dodatku - „o czym nie śniło się filozofom” - traumatyczne doznania zostały w PRL-u objęte procesem tabuizacji, co czyniło tragiczne wydarzenia przymusowej migracji jeszcze boleśniejszymi. Na tej podstawie można by, jak się zdaje, wskazać na potencjalny element nawiązania do hermeneutyki Martina Heideggera w filozoficznym ujęciu człowieka jako bytu absurdalnego, który zostaje „wrzucony” w świat bez pytania go o zdanie w podstawowych dla Ja sprawach egzystencjalnych, dotyczących życia oraz śmierci (Januszkiewicz 2017).

Rzecz wcale nie w tym, żeby sztucznie „mnożyć” konteksty, lecz mikrohistorię, co - jak sądzę - jest uprawomocnioną procedurą rozumienia zjawiska, można odnaleźć w doświadczeniu przymusowej migracji po zakończeniu II wojny przynajmniej w tym aspekcie, że ich uczestnicy, jak na przykład Kresowianie ze wschodnich terytoriów Polski w jej granicach sprzed września 1939, oceniali swoją sytuację jako niepewną oraz przyprawiającą ich o egzystencjalną trwogę, a nawet więcej - o bezsens istnienia. A jednak, niczym bohater utworu Zbigniewa Herberta, napisanego dużo później i w odmiennych realiach historycznych, oni również wracali „na kamienne łono / ojczyzny" (Herbert 1995, 22). Gdy lubelski, komunistyczny rząd, a wcześniej - postanowienia w sprawie terytorium powojennego państwa polskiego na konferencji w Jałcie - rozwiały wszelkie nadzieje Kresowian na włączenie utraconych w ten sposób ziem na Wschodzie do nowo powstałej Polski, masowo podejmowali oni decyzję o opuszczeniu rodzinnych stron. Mimo że w ciągu sześciu lat wojny przywykli do zdarzeń trudnych do wyobrażenia (terror okupanta, sowieckie więzienia, deportacje na Syberię czy do Kazachstanu), jedno było dla nich absolutnie nie do przyjęcia - bycie obywatelami ZSRR. W archiwum Instytutu Zachodniego w Poznaniu 
znajdziemy pamiętniki wysiedleńców z Kresów, wśród nich relację Henryka Zadury, który odsłania jednoznacznie motywację ówczesnych Polaków:

Ciągnęła nas do Polski wielka miłość ojczyzny [podkr. A.R.] - miłość, która kazała opuścić ziemię i zabudowania gospodarskie z takim trudem zdobyte, która przekreślała przyjaźń rówieśników białoruskich i która kierowała nas w nieznane [podkr. A.R.]. Coraz to nowe grupy Polaków ciągnęły jak ptaki na wiosnę - w swój kraj [podkr. A.R] (Halicka 2015, 165).

Z przytoczonego fragmentarycznie wspomnienia wyłoniła się in statu nascendi osobista definicja patriotyzmu autora pamiętnika (wyróżniona graficznie) jako „wielka miłość ojczyzny, która kierowała nas w nieznane, w swój kraj”. Obrazuje ona paradoksalność sytuacji wysiedlanych polskich obywateli: wsiadają do pociągu, nie wiedząc, dokąd jadą: „w nieznane”, ale nadzieja każe im zaufać obcości i uznać niewiadome za „swój kraj”. Na tym przykładzie można się przekonać o mocy symboli. Natomiast nie ma to żadnego znaczenia, że wedle dzisiejszych norm oceny zacytowana wypowiedź może zostać uznana za zbyt patetyczną, że może razić emfaza i emocjonalność słów, lecz została ona ukształtowana przez kulturę jeszcze przedwojenną, dla której podstawą odniesień było dziedzictwo romantyczne, w tym wzorce emigracyjne oraz martyrologiczne. Istotnie, miłość Kresowian do Polski była „wielka” i wymagała determinacji w znoszeniu trudów, a nierzadko - także osobistego poświęcenia, żeby z ZSRR dotrzeć do rodzimego kraju.

\section{Polski exodus: ze Wschodu na Zachód}

$\mathrm{Na}$ oddanie skali oraz zasięgu powojennych migracji badacze zjawiska posługują się często metaforami, by wyrazić niewyobrażalne dla współczesnych zdarzenia. Ponadto odwołanie do Jakobsonowskich funkcji języka (impresywnej, emotywnej i - oczywiście - metajęzykowej) pozwala oddziaływać na odbiorcę tekstu: wyrwać go z codziennej rutyny i nakłonić do namysłu nad sensem przeszłych wydarzeń oraz wyciągnąć wnioski na przyszłość. I tak, Krystyna Kersten używała metafory: „ludzie na drogach” (Zaremba 2012, 357) Eugene M. Kulischer - „Europe on the Move” (Halicka 2015, 154), a za jego przykładem Halicka - „Poland on the Move” (Zaremba 2012, 154), zaś Zaremby sformułowanie „wielka trwoga” (Zaremba 2012), użyte na określenie całokształtu rzeczywistości w Polsce w latach 19441947, zawiera również wygnańcze doświadczenie Kresowian.

Warto przypomnieć, że po europejskich drogach w pierwszych powojennych latach przemieszczały się miliony Polaków. Do końca roku 1946 ze Wschodu, z terenów Polski włączonych do ZSRR przesiedlono: z Ukrainy blisko 800 tysięcy Polaków, z Białorusi 274 tysiące, z Litwy 197 tysięcy, co w jednym tylko roku dało zawrotną liczbę $1 \mathrm{mln} 271$ tysięcy na szacowane 1,5 mln wszystkich Polaków wysiedlonych z Kresów Wschodnich. Równocześnie Polacy powracali też z Zachodu. Z samych Niemiec od 
zakończenia wojny (8 maja 1945 roku) tylko do sierpnia 1945 roku wróciło aż 800 tysięcy ludzi: byłych więźniów, jeńców wojennych i przymusowych robotników, aby w końcu 1947 roku osiągnąć liczbę 1 mln 600 tysięcy powracających osób. Według ustaleń Zaremby w latach 1945-1947 Polaków, „ludzi na drogach”, było ponad 3,5 mln (Zaremba 2012, 357). Wszyscy wracali do kraju wyniszczonego podwójną okupacją w latach 1939-1945, zrujnowanego, pogrążonego w wewnętrznych konfliktach na tle politycznym.

Motyw tamtego zamętu, nieodłącznie towarzyszącego ludności cywilnej, odnajdziemy w tomie poezji Waldemara Żyszkiewicza: Taki lajf. Tejk 7.0 w metaforze „wielkiego ruchu” (Żyszkiewicz 2016, 7). Rekonstruując w poemacie Noga świni czy skrzydełko ptaka autobiograficzne okoliczności własnych narodzin, poeta przekracza osobistą nostalgię i wiąże rodzinne wspomnienia z polityką:

Gdym się rodził

\section{w czterdziestym siódmym}

to mówią po latach

że wielki ruch w przyrodzie

był [podkr. A.R.]. A zwłaszcza w lasach matecznych zdolnych płaszczem okryć dochować tajemnicy

(Żyszkiewicz 2016, 7)

Żyszkiewicz przede wszystkim pyta o sens politycznych rozgrywek, również tych w Polsce owładniętej wojną domową w latach 1944-1947, czego literackim synonimem pozostaje metafora „wielkiego ruchu w przyrodzie”, sugerująca znaczenia popełniania zbrodni politycznych oraz ukrywania ich w tajemnicy, pod „płaszczem lasu”. Nie wszystko udaje się zamaskować i niekiedy, jak w tragediach historycznych Szekspira, dochodzi do ujawniania makabrycznych odkryć. Jednakże dystans temporalny, nieobecność uczestników ówczesnych zdarzeń, pamięć naturalnie zacierająca się z upływem czasu sprawiają, że dziś trudno jednoznacznie orzec:

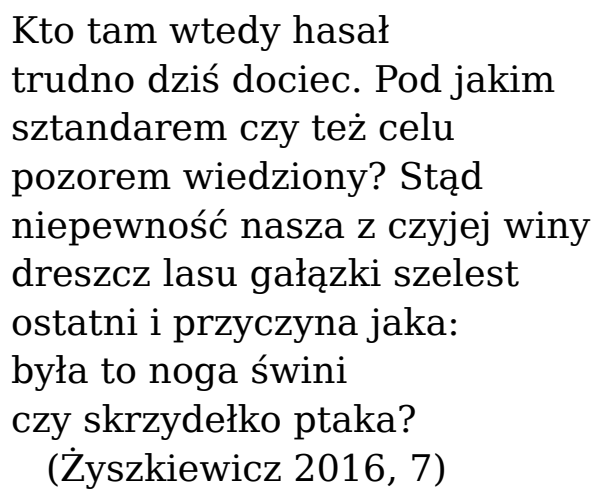

A im dalej od przeszłych zdarzeń, tym więcej trudności napotyka dociekliwy badacz historii. Również w jej prywatnym wymiarze. Jak rozdzielić po latach fakty od interpretacji? Prawdę od zmyślenia? Od przypadkowej pomyłki? Od celowej manipulacji? Główne pytanie o przyczynę, 
oddane w metaforach: „noga świni” (polityczne szwindle) czy „skrzydełko ptaka” (dążenia wolnościowe), tylko pozornie stanowi poznawczą alternatywę. Odpowiedź znamy z prac historyków, także badaczy przywoływanych w tym artykule. Są też motywy ważniejsze od naukowej faktografii, osobiste: honor, godność, sprawiedliwość.

\section{Poznań: w stolicy trzeciego zaboru}

Coraz lepiej znana jest historia Europy w XX wieku. Mimo tej wiedzy polityka nadal nie przestaje być dla przeciętnego człowieka anonimową siłą, która anihiluje jego życie zupełnie na podobieństwo pierwotnych sił przyrody w wyobrażeniu pierwszych ludzi - taka jest groźna i nieubłagana. Karl Schlögel w publikacji Planet der Nomaden (2006) zaznaczył, że w odróżnieniu od dobrowolnej migracji, jej przymusowy wariant „burzy wszelką rutynę i wszelkie przyzwyczajenia. Za sprawą jednego pociągnięcia pióra lub jednej tajnej akcji kończy się wszystko, co wcześniej stanowiło normalne życie" (Halicka 2015, 26). Przesunięcie granicy Polski w kierunku zachodnim, wzdłuż linii Curzona, czego gorącym zwolennikiem był Churchill (Fenby 2007), a w co - mimo krążących pogłosek - Kresowianie nie mogli uwierzyć, stało się złożonym faktem: biograficznym, politycznym, historycznym. Dla nich ojczyzna bez Lwowa i Wilna, bez Niemna Mickiewiczowskiej „domowej rzeki” - była nie do przyjęcia. Absurdalność wydarzenia sprawiła, że zaraz po wojnie, również dla celów propagandowych, powstawały liczne narracje mikrohistoryczne. Nikt ich wtedy tak nie nazywał, lecz przymus migracji dokumentowano w wersji okrojonej zarówno przez samych Kresowian (autocenzura), jak też oficjalnie, przez urzędników cenzury.

Identyczne są również losy przodków Żyszkiewicza, odziedziczone przez poetę wraz z rodzinną opowieścią o przedwojennym Lwowie, o wygnańczej tułaczce zwanej eufemistycznie w języku urzędniczych raportów „repatriacjąa”. Dla Żyszkiewicza, jak i dla późniejszych powojennych roczników, pozostaje ona jednak czysto abstrakcyjnym wyobrażeniem albo polem do postpamięciowej pracy wyobraźni (vide: Dwanaście stacji Tomasza Różyckiego). Nostalgia poety skupia się w utworze: Grunwald i Indianie, którego tytuł może wydawać się nazbyt „literacki” wskutek aluzji do bitwy z Krzyżakami (Grunwald) oraz skojarzeń z serią przygodowych książek Karola Maya (Indianie). Jednakowoż $\mathrm{w}$ trakcie lektury okaże się, że w świecie przedstawionym wiersza nazwa „Grunwald” oznacza administracyjną dzielnicę Poznania z osiedlem Świętego Łazarza. Natomiast drugi człon tytułu jest aluzją do chłopięcych fascynacji światem północnoamerykańskich Indian, do których mógł dostarczyć zachęty pawilon z sukulentami w poznańskiej Palmiarni, ulokowanej w tej części miasta. Ułamki wspomnień z dziejów rodziny łączą się w tym utworze płynnie $\mathrm{z}$ autobiograficznymi doświadczeniami Żyszkiewicza, który z Rzeszowa - tam po wojnie rodzice stworzyli 
miejsce do życia dla siebie i mającego urodzić się dziecka - przyjeżdżał do dziadków, osiedlonych właśnie w Poznaniu:

Pamiętny cel podróży u początków lata. Kamienica

z czerwonej cegły, ze sklepem na rogu. Chłód spiżarni

o wąskim oknie - gotyk stosowany. Ocieniona ulica

poniemiecki kościół, w którym po latach w ślubnej sukni

przejdzie Anna Jantar. Kiedyś... bo teraz

modli się tam babcia Karolina.

Na śniadanie - kajzerki cesarza Wilusia, jak poufale

bez szyderstwa, mówi o nim dziadek. Sam poddany i żołnierz

Franciszka Józefa dzielnie bił się przed laty o Górną Adygę:

kampania włoska, południowy Tyrol. Tam stracił zdrowie

wiarę w cesarzy nadwątlił...

Stanę po latach na brzegu tej rzeki, ale dziś wolę jeszcze żołnierzy z ołowiu: Indian w barwach wojennych, tropicieli

śladów. Pięknych jeźdźców z małego sklepiku w sąsiedztwie,

kiedy u progu lata mocno pachną lipy i ostro dzwoni

tramwaj na zakręcie...

Pamiętny cel podróży: z Dworca Zachodniego

do dziadków, których ze Lwowa na poznański Łazarz tuż po wojnie przeniosła brudna łapa Jałty. I już tam na Górczynie pochowali córkę.

Ciocia Marysia, siostra ojca, po mężu Żyromska wyszła z Auschwitz.

Niestety z rozległą gruźlicą. W czterdziestym siódmym nie przetrwała ataku prosówki.

A trzy miesiące później ja się urodziłem.

Wonne lipy i żołnierzyki... Obrazy z dzieciństwa napłynęły gwałtownie, gdy szło na przedwieczerz. Dziś życie dość przewrotnie rozkłada akcenty. Ciężka lipowa skrzynia. Ornament z ołowiu. Wojska w zasadzie nie ma. I miasto wciąż inne. Dom jednak trwa.

Naprzeciw stoi

Kamienica. Dostatnia, z jasnej cegły wzniesiona na gruzach.

Drzewa wrastają w ziemię, nie dając się wichrom

innych wojen... Znienacka tylko wrzaśnie wrona

jakby chciała wyśpiewać ten motyw z przeszłości,

że śmierć i miłość w finale rzeczy znajdą się

na pewno. Choćby po latach w stolicy

trzeciego zaboru.

(Żyszkiewicz 2016, 12-13)

Finał kresowych dziejów rodziny, ku zaskoczeniu dziadków poety, znalazł swoje miejsce w Poznaniu. Wprawdzie w Polsce, bo po wygranym powstaniu wielkopolskim (1918) stolica Wielkopolski została włączona w granice państwa odzyskującego niepodległość po zaborach, lecz w mieście obcym kulturowo Kresowianom. Śladem odmienności w architekturze Poznania, podobnie do innych miejscowości dawnego zaboru pruskiego, 
pozostała charakterystyczna i niespotykana na wschodzie kraju zabudowa z czerwonej cegły. Występująca w wierszu peryfraza: „w stolicy / trzeciego zaboru”, zastosowana zamiast toponimu: w Poznaniu, określa miasto, do którego po II wojnie przybyli przesiedleńcy, zarazem sygnalizując inność, z jaką zetknęli się po przyjeździe ze Wschodu. Miejsce to dla nich było najdalsze, bo geograficznie i - co jeszcze dotkliwsze - mentalnościowo, najbardziej na zachód wysunięte od okolic Lwowa, co poeta zasugerował, używając liczebnika porządkowego. Podążając tym tropem, uznamy, że w ocenie Kresowiaków pierwszy/najbliższy im zabór to austriacki, na terenie którego położony był Lwów i z jakim łączyła się wojskowa przeszłość dziadka poety (poddanego dobrotliwego cesarza Franciszka Józefa); drugi zabór to rosyjski z Warszawą, a na końcu trzeci - z Poznaniem w centrum.

Zgodnie z mikrohistorycznymi regułami uznamy więc, że „stopniowanie” obcości było chyba nieuniknione w doświadczeniu Polaków wysiedlonych z Kresów. Tak samo jak dziadkowie poety, „których ze Lwowa na poznański Łazarz tuż po wojnie / przeniosła brudna łapa Jałty”, również inni znaleźli się w sytuacji, w której pozbawiono ich wyboru i wpływu na los. Porównajmy: metafora „łapa Jałty” stoi w opozycji do wolności i aktywnych działań, których wyrazem jest potoczna polszczyzna z funkcjonującym w niej frazeologizmem: „brać sprawy w swoje ręce”. Pamiętajmy przy tym, że tuż po wojnie różnice kulturowe między wschodem a zachodem państwa polskiego były znacznie poważniejsze aniżeli dzisiaj. W zasadzie obejmowały one wszystkie sfery życia człowieka: język, tradycje, obyczaje, mentalność. Również kulinaria. Nawet tak „arcypolska” potrawa, jaką są pierogi, pojawiła się w kuchni Wielkopolan dopiero po II wojnie, naturalnie wraz z przybyszami z Kresów Wschodnich. Ponadto słynna lwowska tradycja kulinarna przed II wojną podziwiana była w całej Polsce ze względu na szlachetne powinowactwa z wiedeńskimi smakami, znana z wybornej kawy i wykwintnych ciasteczek oraz tortów. W tym na pewno lwowiacy mogli czuć bliskość kulturową Poznania, że w mieście nad Wartą piło się czarną kawę, a nie herbatę, co odzwierciedlają również aktualne badania marketingowe.

W codziennym mozole udawało się Kresowianom oswoić obce polskie miasta noszące kulturowe znaki niegdysiejszej przynależności do pruskiego zaborcy. Służyły temu celowi pielęgnowane w domu drobne rytuały, na przykład jadane „Na śniadanie - kajzerki cesarza Wilusia”. Szczegół z wiersza w rodzaju określenia „przynależności” bułeczek nie do Austriaka, Franciszka Józefa, wskazuje, że również cesarza Niemiec można było nazywać „bez szyderstwa”, a może nawet z sympatią, na co wskazuje nieoficjalne zdrobnienie imienia Wilhelm. Centrum życia lwowskiej rodziny Żyszkiewiczów odbudowane po II wojnie światowej znalazło nową, materialną lokalizację właśnie w „poniemieckiej” kamienicy. Zapewne, taki obrót życiowych spraw pozytywnie wpłynął na percepcję miejsca osiedlin, i, równocześnie, przyjazne nastawienie do cesarza Wilhelma II, który 30 marca 1900 roku wydał dekret o wcieleniu Łazarza do Poznania. Było to drugie 
takie wydarzenie w „mikro” - historii dzielnicy, po pierwszym włączeniu tych gruntów do miasta, w 1797 roku (Kędelski 1998, 9).

W omawianym utworze nie tylko kościół świadczył przecież o dawnym, pruskim dziedzictwie wielkomiejskiego kwartału, ale też wspomniana kamienica, zbudowana z charakterystycznej czerwonej cegły. W wersie: "Chłód spiżarni/o wąskim oknie - gotyk stosowany" (TL 12) przykuwa uwagę kolejna oryginalna peryfraza występująca w wierszu: "gotyk stosowany”. Kierując się wiedzą z zakresu poetyki, powiemy, że jest to hiperbola. Może się wydawać, że przymiotnik "stosowany" występujący przy rzeczowniku "gotyk" trywializuje podniosły styl architektoniczny, w jakim wznoszono w średniowieczu europejskie katedry. Jednakowoż ze względu na fakt, że jest to następne aluzyjne nawiązanie do pozaborowego dziedzictwa Łazarza, potraktować je trzeba jako uznanie dla słynnych niemieckich architektów, projektantów dzielnicy. Bowiem kamienice wznoszone w początkach XX wieku w tej części Poznania, podług modernistycznych planów, w niczym (prócz ceny) nie ustępowały budowanym wówczas w Berlinie oraz w innych miastach Niemiec. Wyposażone w centralne ogrzewanie, łazienki, z przyłączoną elektrycznością i gazem, odznaczały się wysokim standardem użytych materiałów i wykończenia, a także świetnie komponowały z otaczającą je zielenią. Tworzyły z nią integralną i harmonijną całość, cenioną przez przedwojennych lokatorów dzielnicy. Aleje starych lip przy budynkach Łazarza nie są w wierszu wytworem wyobraźni poety, owym nieodłącznym komponentem idylli dzieciństwa czy dostojnym spadkiem po tradycji czarnoleskiej Jana Kochanowskiego; przynależą do prywatności Żyszkiewicza, odnajdziemy je w rzeczywistej topografii Poznania.

Chociaż w poetyckim wspomnieniu poety babcia Karolina westchnie: „- Wszystko się rozsypało” (Żyszkiewicz 2016, 16), ale pierwszy grób na obcej ziemi - „cioci Marysi” - przypieczętuje ostatecznie związek z nowym miastem i unieważni bolesną barierę obcości. Na mapie rodzinnej pamięci, na mocy niewidzialnych wyroków losu ten tragiczny fakt mieści się obok wydarzenia szczęśliwego, jakim były narodziny dziecka, zamykające w ten sposób etap bolesnych zdarzeń w historii rodziny. Poeta powie więc z przekonaniem: „że miłość i śmierć w finale rzeczy znajdą się/na pewno" (Żyszkiewicz 2016, 13). W końcu przybysze ze Lwowa odbudowali w Poznaniu zniszczone życie. Obrawszy mikrohistoryczną perspektywę, zogniskowaną na metaforze rozpadu egzystencji, można by uznać szczęśliwy finał losów rodziny z Kresów za zaskakujący. Tak też, z głębokim niedowierzaniem, mógł być odbierany przez przymusowych migrantów, jak w poetyckiej konstatacji w wierszu: Dom jednak trwa (Żyszkiewicz 2016, 12). Udało się "jednak" scalić rodzinę i roztrzaskane fragmenty wojennych życiorysów w ramach jednego obrazu. Widać na nim linie pęknięć, widać też „lepiszcze” w postaci okruchów codzienności, które niczym cegiełki stają się fundamentami nowego życia. Równocześnie trwanie domu, w jakiś nieodgadniony sposób wykracza poza wymiar egzystencji pojmowanej czysto 
materialnie. Zarazem można w tym przekonaniu poety upatrywać istnienia tajemnicy spoza ziemskiego porządku bytu i czerpać z niego metafizyczną otuchę. Podobnie do babci, która klękała w domu do modlitwy, wpatrując się w sacrum „Madonny przywiezionej z Kresów” (Żyszkiewicz 2016, 17) albo szła do pobliskiego kościoła pod wezwaniem św. Anny, który w 1907 roku wzniosła „Ewangelicka parafia kościelna Chrystusa w Poznaniu” (Kiec 1998, 94). Świątynia, podobnie do szpalerów lip i kasztanowców, które ocieniają stary Łazarz, ocalała z nalotów alianckich w Wielkanoc 1944 roku i mimo frontu, jaki przetoczył się przez miasto zimą 1945 roku. Śladem tamtych wydarzeń jest w występująca w wierszu wzmianka o gruzach pozostałych po zbombardowanej w sąsiedztwie kamienicy i o nowej wzniesionej w tym miejscu. A więc nie tylko przybyli do miasta Kresowianie - także poznaniacy, zaczynali swe powojenne życie od podnoszenia się z ruin.

Natomiast w innym utworze Żyszkiewcza pt. Kawa po turecku ogląd Poznania poszerza się o teren spoza łazarskiej dzielnicy. W serii migawek, w czasie jazdy tramwajem linii nr 5 z Górczyna w kierunku Stomil, odtwarzane są w nim charakterystyczne szczegóły przynależące do topografii miasta: „tuż obok Święty Marcin pije kawę po turecku / z łoskotem zjeżdża tramwaj na plac Wiosny Ludów” (Żyszkiewicz 2016, 16). „Święty Łazarz” w omawianym tomie poezji jest rodzajem toponimu, podobnie „Święty Marcin” nie funkcjonuje w wierszu jako przykład antroponimu, lecz oznacza nazwę ulicy. Mieszcząca się przy niej kawiarnia „Kociak” dziś jest uznawana za „kultową” i blisko z niej do kina „Muza”, najstarszego w Poznaniu (od 1908 roku). Dlatego dygresja poety o kawie serwowanej „po turecku” świadczy o tej fazie oswajania obcego miasta, kiedy już wychodzi się z domu, aby włączyć się w rytm miasta i uczestniczyć w jego przestrzeni symbolicznej. Wszak „picie kawy”, znaczy więcej od spożywania gorącego napoju o pobudzającym działaniu - przyjemność spotkań towarzyskich.

Nawiązując na koniec do wniosków badaczy zjawiska migracji: Oswald, Halickiej, Zaremby, podkreślamy dewastujący egzystencję zwykłych ludzi wymiar przymusowych przesiedleń wojennych i tużpowojennych. Z drugiej strony, akcentujemy też możliwość przezwyciężenia utraty rodzinnych stron oraz osobistej wygnańczej nostalgii, włączywszy się w nurt codziennego życia w miejscu osiedlin.

\section{Dwudziestowieczność}

Zwykle to na wstępie wypowiedzi odnotowuje się fakty biograficzne dotyczące autora, o jakim powstaje artykuł. Tutaj odwracam ten porządek kompozycji, przekonana, że wpierw należałoby przypomnieć tło historyczne wydarzeń znajdujących literacką reprezentację w poezji. Powojenne migracje są tematem olbrzymim, coraz lepiej znanym. Nadal jednak są obecne w społecznej świadomości trwałe ślady peerelowskiej mitologizacji tematu, wobec czego zdecydowałam się szerzej, niż to pierwotnie planowałam, przedstawić badania najnowsze, z XXI wieku, w których czytelnik znajdzie 
kompetentne opracowanie tematu powojennych migracji. Refleksja nad tymi dramatycznymi zdarzeniami mogłaby, jak sądzę, towarzyszyć lekcjom, na których porusza się pokrewne wątki historyczne, na pewno wojnę, czy też wszechobecny chaos tuż po jej zakończeniu. Dodatkowo mikrohistoryczny walor poetyckiej opowieści Żyszkiewicza pozbawia jego poetycką narrację kontekstu martyrologicznego i patosu. Za to dobrze ilustruje relacje utrzymane między indywidualną biografią a wielką historią, miejscem życia, przeszłością rodziny. Poza tym ciekawa dla młodzieży może być także wycieczka na poznański Łazarz, do Palmiarni, połączona z obejrzeniem kamienicy $\mathrm{z}$ wiersza. Ta monumentalna budowla stanowi przykład kamienicy narożnikowej, stoi na skrzyżowaniu ulic Matejki nr 44-49 z Limanowskiego 10 vis-à-vis, przy ul. Matejki nr 42 jest kościół św. Anny w stylu neogotyckim, tak charakterystycznym dla niemieckiego budownictwa sakralnego z początków XX wieku.

Życiorys Waldemara Żyszkiewicza, podobnie jak całego pokolenia Polaków urodzonych zaraz po wojnie, został uformowany przy współudziale potężnych sił europejskiej i krajowej polityki. Poeta o tym pamięta w całym zbiorze wierszy, z którego pochodzą przytoczone w artykule przykłady. Dwudziestowieczność, w jego interpretacji, to przede wszystkim „epoka polityczna", jak w wierszu Wisławy Szymborskiej Dzieci epoki, z tomu Ludzie na moście (1986). Żyszkiewicz ma świadomość swego kresowego dziedzictwa, pomimo że urodził się w Rzeszowie, dokąd dotarli rodzice po opuszczeniu wiosną ' 44 rodzinnego Lwowa, lecz nigdy nie przestawali wspominać ukochanego miasta. Natomiast dziadkowie „po mieczu” osiedlili się po wojnie w Poznaniu, gdzie chętnie odwiedzał ich wnuk. Ale to nie koniec migracji autora, który z młodzieńczą dezynwolturą zatytułował najnowszy tom wierszy: Taki lajf. Tejk 7.0, ponieważ w latach 60. XX wieku zatrzymał się na dłużej w Anglii, u wuja, żołnierza generała Stanisława Maczka, również pojałtańskiego wygnańca. Ponadto Żyszkiewicz mieszkał także w Szwecji, a w Polsce - w Krakowie i w Warszawie (osiadł w stolicy dwadzieścia lat temu), gdzie dziś mieszka. W boleśnie ironicznej poincie poeta stwierdził, że na czasie jego narodzin, w 1947 roku, piętno odcisnął „wielki ruch” polityków i towarzyszyła mu proporcjonalna do niego „wielka trwoga” zwykłych ludzi umęczonych „wielką wędrówką”. W zgodzie z faktami można podsumować, że wymuszona przez historię ruchliwość ludności kresowej była nie mniej niebezpieczna, dramatyczna, co dopiero co zakończona wojna, i zmuszała do przewartościowania całego życia na skutek przesunięcia granic, rozumianych nie tylko terytorialnie.

\section{Bibliografia:}

Bakuła Bogusław, 1997, „Z Kresów na Kresy”. Migracje społeczeństwa polskiego w literaturze krajowej po 1945 r., w: Utracona ojczyzna. Przymusowe wysiedlenia, deportacje i przesiedlenia jako wspólne doświadczenie, Orłowski H., Sakson A. (red.), Poznań, s. 225-237. 
Domańska Ewa, 2005, Mikrohistorie. Spotkania w międzyświatach, Poznań.

Fenby Johnatan, 2007, Alianci. Stalin, Roosevelt, Churchill. Tajne rozgrywki zwycięzców II wojny światowej, Pietrzyk B., Rumińska J. (przeł.), Kraków.

Grzebałkowska Magdalena, 2015, 1945: wojna i pokój, Warszawa.

Halicka Beata, 2015, Polski Dziki Zachód. Przymusowe migracje i kulturowe oswajanie Nadodrza 1945-1948, Łuczak A. (przeł.), Kraków.

Herbert Zbigniew, 1995, Raport z oblężonego Miasta i inne wiersze, Wrocław.

Jakobson Roman, 2006, Poetyka w świetle językoznawstwa, w: Teorie literatury XX wieku. Antologia, Burzyńska A., Markowski M.P. (red.), Kraków.

Januszkiewicz Michał, 2017, Być i rozumieć: rozprawy i szkice z humanistyki hermeneutycznej, Kraków.

Kersten Krystyna, 1997, Przymusowe przesiedlenia ludności. - Próba typologii, w: Utracona ojczyzna. Przymusowe wysiedlenia, deportacje i przesiedlenia jako wspólne doświadczenie, Orłowski H., Sakson A. (red.), Poznań, s. 13-29.

Kędelski Mieczysław, 1998, Ludność Łazarza i Górczyna w XIX wieku i na początku XX wieku, w: „Kronika Miasta Poznania: Święty Łazarz”, nr 3, s. 9-28.

Kiec Olgierd, 1998, Ewangelicka parafia Chrystusa na Łazarzu, w: „Kronika Miasta Poznania: Święty Łazarz", nr 3, s. 87-108.

Motyka Grzegorz, 2016, Wołyń '43: ludobójcza czystka - fakty, analogie, polityka historyczna, Kraków.

Orłowski Hubert, 1997, „Dwugłos w miejsce wstępu. Wokół utraconych $<<$ ojczyzn prywatnych>>", w: Utracona ojczyzna. Przymusowe wysiedlenia, deportacje i przesiedlenia jako wspólne doświadczenie, Orłowski H., Sakson A. (red.), Poznań, s. 10-12.

Słownik języka polskiego PWN (wersja elektroniczna), 2004, Warszawa, t. 1-3.

Snyder Timothy, 2009, Rekonstrukcja narodów. Polska, Ukraina, Litwa, Białoruś, 1569-1999, Sejny.

Wiegandt Ewa, 1988, Austria Felix, czyli o micie Galicji w polskiej prozie współczesnej, Poznań.

Wołyń, reż. Wojciech Smarzowski, 7 października 2016 (data premiery w Polsce).

Zaremba Marcin, 2012, Wielka trwoga. Polska 1944-1947. Ludowa reakcja na kryzys, Kraków.

Żyszkiewicz Waldemar, 2016, Taki lajf. Tejk 7.0, Sopot.

\section{O Autorce:}

Agnieszka Rydz - dr hab., pracuje jako profesor w Instytucie Filologii Polskiej Uniwersytetu im. Adama Mickiewicza w Poznaniu, którego jest absolwentką. Autorka książek: Mnemozyna. Pamięć autobiograficzna w poezji polskiej (Poznań 2011), Świat nie ma sensu. Sens ma sztuka. O powojennej poezji Kazimierza Wierzyńskiego (Warszawa 2004). Zajmuje się poezją dwudziestowieczną i najnowszą w kontekstach dyskursów ponowoczesnych (pamięć, afekt, migracja). 
